\title{
Management of high-risk and advanced basal cell carcinoma
}

\author{
S. Puig • A. Berrocal
}

Received: 16 December 2014/ Accepted: 22 December 2014/Published online: 3 February 2015

(c) The Author(s) 2015. This article is published with open access at Springerlink.com

\begin{abstract}
Despite that basal cell carcinoma (BCC) is curative in the vast majority of cases, some patients are at high risk of recurrence and, in a few patients, lesions can progress to a point unsuitable for local therapy and prognosis is quite poor. The aim of the present work is to review clinical and pathologic characteristics as well as classical and new treatment options for high-risk, metastatic and locally advanced BCC. Surgery and radiotherapy remain the selected treatments for the majority of high-risk lesions. However, some patients are located on a blurry clinical boundary between high-risk and locally advanced BCC. Treatment of these patients is challenging and need an individualized and highly specialized approach. The treatment of locally advanced BCC, in which surgery or radiotherapy is unfeasible, inappropriate or contraindicated, and metastatic BCC has changed with new Hedgehog pathway inhibitors of which vismodegib is the first drug approved by FDA and EMA.
\end{abstract}

Keywords Basal cell carcinoma $\cdot$ High-risk BCC . Locally advanced BCC $\cdot$ Metastatic BCC $\cdot$ Mohs micrographic surgery $\cdot$ Hedgehog pathway inhibitors

S. Puig ( $\square)$

Melanoma Unit, Dermatology Department, Hospital Clínic

Barcelona, IDIBAPS, University of Barcelona, Villarroel 170, 08036 Barcelona, Spain

e-mail: susipuig@gmail.com; spuig@clinic.ub.es

S. Puig

Centro Investigación Biomédica en Red en Enfermedades Raras (CIBERER), Barcelona, Spain

A. Berrocal

Oncology Service, Hospital General Universitario de Valencia,

Valencia, Spain

\section{Introduction}

Basal cell carcinoma (BCC) is the most common malignant tumor of the skin and is also the most common human malignancy. The incidence of BCC is increasing in many countries around the world. The underlying cause of BCC is unknown, but ultraviolet light exposure and genetic predisposition seem to be the most significant etiological factors [1]. Aging of the population and frequent exposure to sunlight may explain the worldwide increase that has been observed in the incidence of this malignancy [2].

The goal of treatment of BCC according to the National Comprehensive Cancer Network (NCCN) is cure and maximal preservation of function and cosmetics [3]. Early treatment of $\mathrm{BCC}$ is curative in the vast majority of cases, thus preventing progression with local approaches such as surgical excision, radiotherapy, topical imiquimod, or photodynamic therapy [4]. The likelihood of recurrence following treatment is used to categorize lesions as low or high risk. Thus, high-risk BCC denotes primary or already relapsed tumors with a significant risk of further relapse after local treatment. The overall 5-year recurrence rate has been estimated to be around 4-5\% [5]. Surgery and radiotherapy are the treatment of choice for most patients with high-risk lesions [6].

Despite that advanced disease is rare, $\mathrm{BCC}$ can progress to a point unsuitable for local therapy and prognosis for these patients is quite poor. New treatment options for BCC that inhibit the Hedgehog pathway have led to a redefinition of advanced BCC that includes metastatic BCC and locally advanced BCC $[7,8]$. Metastatic BCC is extremely uncommon, with an incidence ranging from 0.0028 to $0.5 \%$ [9]. The most common areas of metastasis are lymph nodes, lungs, bone and parathyroid glands [10]. In turn, locally advanced BCC refers to lesions that are not 
appropriate for surgery, with medical contraindications for surgery or for whom surgery would result in substantial morbidity or deformity according to the treating physician. The aim of the present work is to review clinical and pathologic characteristics as well as classical and new treatment options for high-risk, metastatic and locally advanced BCC.

\section{High-risk BCC}

Treatment decisions in patients with BCC are usually made on the basis of an estimate of the risk of recurrence. This estimation takes into account clinical and pathologic prognostic factors associated with a high risk of aggressive behavior and a high risk of tumor relapse after primary treatment with curative intent. Firstly, it should be noted that some important clinical features, such as age, duration of lesion and gender do not define high risk of relapse [11]. On the other hand, clinical features defining high risk of relapse include infiltrative growth margins, size, tumor location, histological subtype, recurrent-refractory tumors and previous history of radiotherapy.

Aggressive, infiltrating tumors are frequently ulcerated and have ill-defined margins [12]. In turn, ulcerated BCC is usually larger than non-ulcerated tumors and may be locally destructive. A size larger than $3 \mathrm{~cm}$ has been described as a high-risk feature [13]. Notwithstanding the foregoing, this risk factor has been more accurately defined as $1 \mathrm{~cm}$ for head and neck tumors and more than $2 \mathrm{~cm}$ in other body areas [11]. Tumor location is important as a prognostic factor and a classification in three groups has been proposed accordingly. Thus, trunk and limbs are considered low-risk areas, forehead, cheek, chin, scalp and neck are intermediate-risk areas and, finally, nose and periorificial areas are high-risk areas [11]. Histological subtype should also be taken into account to establish the risk of relapse. The morpheaform, the sclerosing, the infiltrating, the micronodular and the metatypical subtypes are associated with higher risk of relapse $[3,4,11,12,14$, $15]$ as compared to the risk associated with the superficial and the nodular forms. Perineural invasion has prognostic value and its presence is associated with a higher risk of relapse $[11,12]$. In contrast, vascular invasion seems to be of no importance. There is no agreement on the prognostic significance of other factors such as a previous history of radiotherapy, for which a retrospective study found an association [16] whereas others consider this issue as a controversial one [11]. Nevertheless, it is considered that more than $30 \%$ of BCCs have mixed pathology, combining less and more aggressive subtypes (i.e., nodular BCC with areas of infiltrating BCC) [12].

Treatment of high-risk BCC includes several options associated with different levels of aggressiveness. Therefore, it is of the utmost importance to ascertain which patients should be treated with an aggressive approach and which patients may perform well with a less invasive treatment. This decision should be taken on the basis of an evaluation of both the performance status of the patient and the risk of relapse. Table 1 summarizes recommendations from major clinical guidelines to treat high-risk BCC.

A non-surgical approach of high-risk BCC may be the best option for a well-defined subset of patients. Indeed, patients who refuse surgery, those who are elderly or patients with poor general health can be best managed with radiotherapy or other local less aggressive treatments. Moreover, local treatment of recurrent non-aggressive (nodular or superficial types) BCC is controversial [17] and these tumors may not require an aggressive approach.

In contrast, relapsed aggressive forms of BCC benefit from a wide surgical management with the goal of
Table 1 Management of highrisk BCC. Recommendations from clinical guidelines

\begin{tabular}{ll}
\hline $\begin{array}{l}\text { Guideline, year } \\
\text { (references) }\end{array}$ & Recommendations \\
\hline Sterry 2006 [15] & $\begin{array}{l}\text { High-risk positive margins or tumor }>2 \mathrm{~cm} \text { in high-risk site: MMS } \\
\text { High risk with cosmetic concerns or fragile patients: photodynamic therapy, } \\
\text { imiquimod, radiotherapy } \\
\text { Recurrent tumors: }>2 \mathrm{~cm} \text { or infiltrative or high-risk site: MMS }\end{array}$ \\
Dandurand 2006 [11] & $\begin{array}{l}\text { High-risk tumors or previous incomplete resection: MMS when available } \\
\text { Multidisciplinary team decision in selected cases }\end{array}$ \\
Telfer 2008 [6] & $\begin{array}{l}\text { High-risk positive margins or tumor }>2 \text { cm in high-risk site: MMS } \\
\text { High risk with cosmetic concerns or fragile patients: photodynamic therapy, } \\
\text { imiquimod, radiotherapy }\end{array}$ \\
Recurrent tumors: $>2$ cm or infiltrative or high-risk site: MMS \\
MMS for primary high-risk and recurrent tumors \\
MMS for nodular tumors in H and M areas (see text) \\
HCCN 2013 [3]
\end{tabular}

MMS Mohs micrographic surgery 
achieving a complete resection, the best example of which is Mohs micrographic surgery (MMS) (Fig. 1). This complex surgical technique is focused on an extremely accurate assessment of margin status [18]. Achievement of marginfree of tumor invasion is crucial to avoid relapse either in high-risk or in locally advanced tumors. More specifically, MMS is a highly specialized microscopically controlled surgical technique aimed at removing complex or advanced skin tumors with poorly defined borders allowing histological examination of the entire surgical margin [19]. The
Mohs surgeon should act as both a surgeon and a pathologist and should thus examine the microscopic margin status after removing the tumor. When used to treat patients with BCC, MMS is generally reserved for highrisk facial lesions (although not exclusively). As MMS is a very demanding technique, not all practicing dermatologists are well trained or have enough experience to conduct an MMS safely. However, the practice of MMS has clearly been rising in the last 15 years worldwide [20, 21]. Although strong evidence from randomized trials is lacking
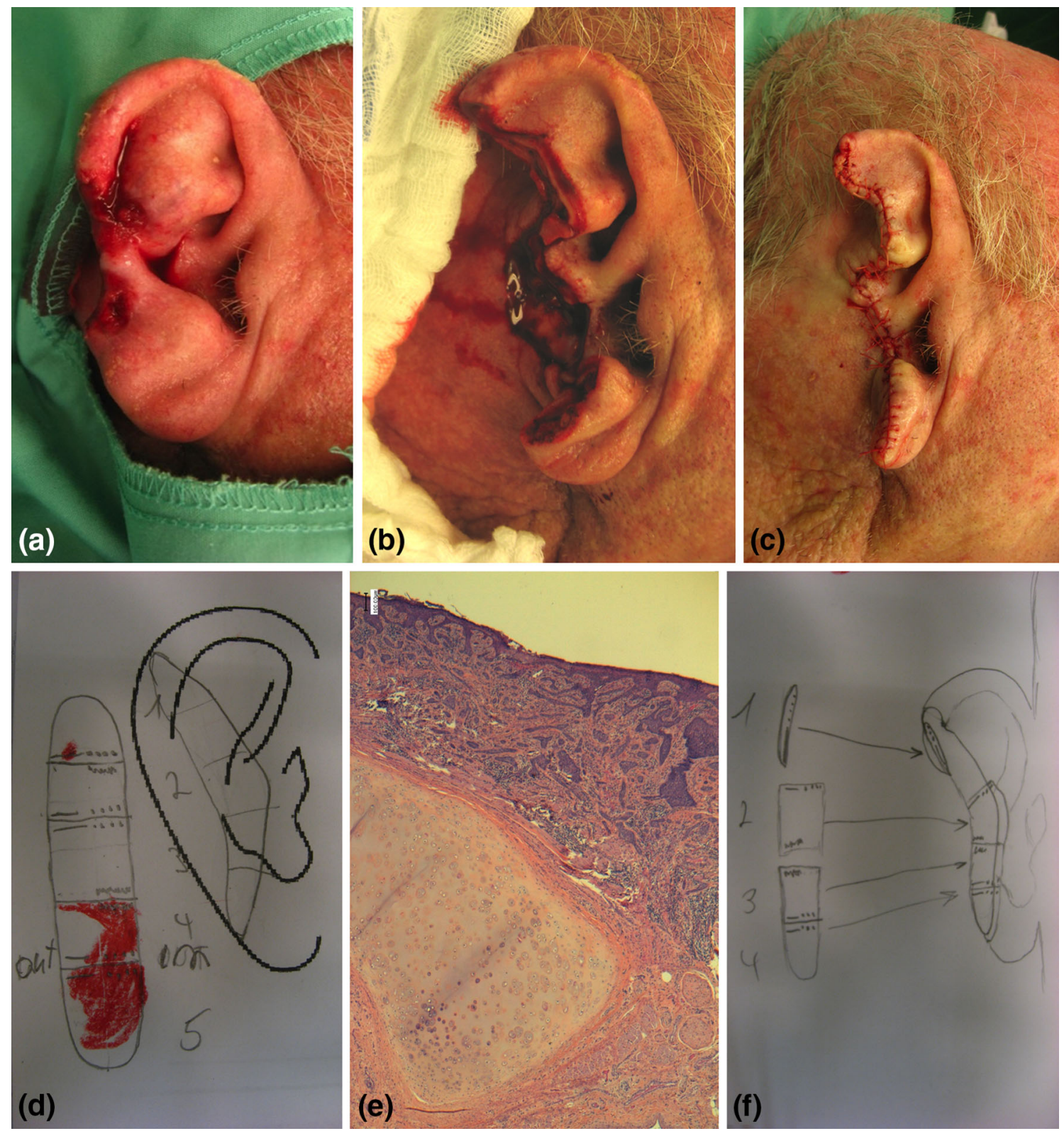

Fig. 1 High-risk basal cell carcinoma on the ear. a Large sclerosing ulcerated plaque infiltrating and eroding the ear helix. A punch biopsy confirmed the presence of infiltrating basal cell carcinoma (BCC). b Final defect after 2 Mohs surgery stages and $\mathbf{c}$ side-to-side clousure. d Stage I Mohs map showing positive deep and lateral margins affected and e the ear cartilage (hematoxylin and eosin staining, original magnification $\times 40$ ). f Stage II showed no residual BCC. Courtesy of Dr Zilinsky and Dr Bennassar 
in the setting of $\mathrm{BCC}$ [22], one of the most important randomized trials performed to date in this setting addressed the use of MMS or surgical resection in facial BCC. Indeed, long-term results showed that MMS resulted in a lower rate of recurrences than surgical excision in the group of patients with relapsed BCC and differences in patients with primary BCC were non-significant [23]. Nevertheless, a consensus meeting sponsored by several academic institutions in the USA agreed on the appropriateness of the MMS approach for high-risk BCC located in different body areas [19]. In this consensus work, human body skin was split into three areas, $\mathrm{H}$ as high- (mask areas of face including central face, nose, eyelids, chin, ear, genitalia, hands, feet, nipples-areola, ankles), $\mathrm{M}$ as medium- (cheeks, forehead, scalp, neck, jawline, pretibial surface) and L as low-risk area (trunk and extremities, excluding $\mathrm{H}$ and $\mathrm{M}$ areas). In short, MMS was considered appropriate for almost every recurrent tumor and primary aggressive tumors. On the other hand, in patients with primary nodular tumors, performing MMS was considered appropriate for tumors sited at $\mathrm{H}$ and $\mathrm{M}$ areas and inappropriate (or of uncertain value) in most patients with tumors in the $\mathrm{L}$ area. Strategies including MMS aiming to manage special situations, such as tumors sited in previous irradiated skin, in traumatic scar, over an osteomyelitis, over an ulcer, over chronic inflammation and in patients with genetic syndromes, were all considered appropriate.

There are patients with high-risk tumors for whom management with local treatments such as surgical excision, MMS or radiotherapy may be very difficult and may lead to excessive morbidity and disfiguration. Moreover, achievement of tumor-free margins is difficult in these tumors. Therefore, these patients seem to be located on a blurry clinical boundary between high-risk and locally advanced BCC, which is also poorly defined from an academic viewpoint.

\section{Locally advanced BCC}

Since BCC arises more frequently in the head and neck, the tumor may infiltrate the eye, nose, facial bones, skull or brain and result in significant symptoms and complications [24]. Thus, the tumor may invade the external auditory canal, auricular cartilage, temporal bone [25], base of the skull leading to cranial nerve palsies [26], brain causing central neurologic symptoms, face with cosmetic problems, calvaria [27] or eye leading to sight problems [28]. In such cases, treatment with surgery or radiotherapy can lead to the loss of sensory organs and their functions.

Although the best treatment for patients with locally advanced tumors is controversial, if the tumors are nonmetastatic and local control may be achieved with surgery when technically feasible, this option should always be considered [29]. Thus, locally advanced tumors are managed, when feasible, with MMS aiming to achieve clear margins and ultimately the cure of the patient. However, this technique, used alone, may not be enough for treating these cases. Therefore, management of these patients may require very complex surgical procedures performed by multidisciplinary teams. These patients are challenging and thereby need an individualized and highly specialized approach. Table 2 summarizes treatment and outcome of

Table 2 Selected case reports of BCC locally advanced or metastatic with curative intent

\begin{tabular}{|c|c|c|c|}
\hline $\begin{array}{l}\text { Author, year } \\
\text { (references) }\end{array}$ & Clinical summary & Treatment & Outcome/follow-up \\
\hline Bozikov 2006 [46] & $\begin{array}{l}\mathrm{T} \text { in ear } 3 \mathrm{~cm} \text {; } \mathrm{M} 1 \text { cervical } \\
\text { lymphadenopathy }\end{array}$ & $\begin{array}{l}\text { Surgical resection with selective } \\
\text { cervical lymph node dissection }+ \text { RDT }\end{array}$ & No follow-up \\
\hline Berlin 2002 [14] & $\begin{array}{l}\mathrm{T} \text { in back } 3 \mathrm{~cm} \text {; M1 axillary } \\
\text { lymph nodes }\end{array}$ & MMS + axillary selective dissection & No recurrence after 18 months \\
\hline Fantini 2008 [47] & $\mathrm{T}$ in axillary skin $1.5 \mathrm{~cm}$, fixed & $\begin{array}{l}\text { Wide resection }+ \text { axillary } \\
\text { lymphadenectomy }\end{array}$ & $\begin{array}{l}\text { After } 1 \text { year local relapse; } \\
\text { after } 2 \text { years bone and lung M1 }\end{array}$ \\
\hline Montgomery 2008 [48] & Multiple $\mathrm{T}$ in trunk & $\begin{array}{l}\text { Preoperative radiotherapy } \\
\rightarrow \text { surgery }\end{array}$ & No follow-up \\
\hline Majima 2012 [49] & $\mathrm{T} 3 \mathrm{~cm}$ in back & Surgical resection & $\begin{array}{l}\text { After } 4 \text { years M1 supraclavicular } \\
\text { and after lung M1 }\end{array}$ \\
\hline Wadhera A 2006 [10] & $\mathrm{T} 1.5 \mathrm{~cm}$ in ear & MMS & $\begin{array}{l}\text { Local relapse after } 5 \text { years } \rightarrow \text { MMS } \\
\rightarrow \text { after } 1 \text { year } \\
\text { parotid M1: resection and } \\
\text { radiotherapy. No relapse } \\
\text { after } 2 \text { additional years }\end{array}$ \\
\hline Mencía 2005 [50] & 80 years. $\mathrm{T}$ in lacrimal caruncle & Surgical resection & No recurrence after 7 years \\
\hline
\end{tabular}

$T$ tumor, $R D T$ radiotherapy, $M 1$ metastases and $M M S$ Mohs micrographic surgery 
selected cases of locally advanced BCC reported in the literature. Another option to consider in the management of these tumors is radiation therapy, alone or with salvage surgery if necessary $[30,31]$.

The treatment options for those patients in which surgery is technically unfeasible were really limited until recently. Thus, a non-surgical approach to treat locally advanced BCC was sequential chemoradiation, which has been used as a treatment for giant locally advanced BCC. Cisplatin alone or in combination has been the most frequently used chemotherapy agent as part of these regimens [32]. However, chemoradiation treatment results in a transient control of tumor growth and ultimately the patient suffers tumor progression. Therefore, this strategy should be considered palliative.

\section{Metastatic BCC}

The presence of multiple primary tumors in the region of the head and neck is one of the risk factors associated with the occurrence of metastasis [33]. Thus, between 85 and $90 \%$ of metastatic BCC is due to head and neck primary tumors [10]. Metastatic BCC includes patients with distant metastases (bone, lung, liver) or lymph node involvement. The median overall survival for patients with metastatic disease is 8 months [9].

These patients require systemic therapy aimed at achieving an improvement in overall survival. Management of metastatic BCC with chemotherapy has not been widely used thus far. In spite of a very small number of reported cases experiencing a transient tumor response with platinum-based chemotherapy [34-36], there is general agreement in that the results of systemic chemotherapy are poor when treating these patients. Therefore, new treatment options are clearly needed, and to move forward enrollment of these patients in clinical trials should be encouraged.

\section{New therapeutic strategies}

Locally advanced and metastatic BCC leads to severe complications secondary to important local tumor growth and can be life threatening. In addition, the QoL of these patients is severely impaired as a consequence of the morbidity, the local symptoms and the cosmetic impact of this disease. As we have outlined, results of the classic treatment are disappointing.

The periorbital area, as an example, is a special one because of both, the well-known predilection of BCC for this site and because cosmetic and functional concerns. Use of the MMS technique [37-39] or plastic surgery techniques with reconstruction [40] are options to treat these
Table 3 Hedgehog pathway inhibitors. Smoothened (Smo) receptor Inhibitors

\begin{tabular}{ll}
\hline Compound & Company \\
\hline Vismodegib (GDC-0449) & Roche, Genentech \\
Sonidegib (LDE225) & Novartis \\
LY2940680 & Eli Lilly \\
BMS-833923 (XLI139) & Bristol-Myers Squibb \\
LEQ-506 & Novartis \\
TAK-441 & Millenium Pharmaceuticals \\
Saridegib (IPI-926) & Infinity Pharmaceuticals \\
PF-04449913 & Pfizer \\
\hline
\end{tabular}

tumors with the goal of protecting the eyeball. As expected, incomplete resection is the main risk factor for recurrence of peri-orbital BCC [41]. Nevertheless, locally advanced $\mathrm{BCC}$ in this area may ultimately require orbital exenteration [42]. Therefore, the need of new therapeutic strategies and enrollment in clinical trials should be clearly underlined in the daily management of patients with locally advanced and metastatic BCC.

Recent advances in our understanding of the molecular pathways that are involved in the proliferation of BCC tumor cells have led to the development of new targeted therapies. The Hedgehog (Hh) pathway is abnormally activated in patients with both sporadic and inherited BBCs (Gorlin syndrome), and inhibition of this pathway appears to result in significant clinical responses. Mutations in PTCH1 (Patched 1) and SMO (smoothened) proteins of the Hh pathway appear to be the most common ones in BCC [43]. There are currently several novel Smo inhibitors (Table 3), one of which-vismodegib-has obtained FDA's and EMA's approval in 2012 and 2013, respectively.

To date, results from three clinical trials with vismodegib have been published [SHH3925g (phase I, $n=33$ ), ERIVANCE BCC (phaseII, $n=104$ ) and STEVIE (phase II, $n=1,229$ )] in metastatic BCC and locally advanced BCC [7, 8, 44]. Locally advanced BCC patients had cutaneous lesions that were larger than $1 \mathrm{~cm}$ and inappropriate for surgery (inoperable, multiply recurrent where curative resection deemed to be unlikely or for whom surgery would result in substantial deformity or morbidity) and for which radiotherapy was unsuccessful or contraindicated or inappropriate [8]. ERIVANCE trial showed overall response rates of $48.5 \%$ in metastatic cohort and $60.3 \%$ in locally advanced patients with a median duration of response of 14.8 months in metastatic BCC and 26.2 months in locally advanced BCCs $[8,45]$. In the STEVIE clinical trial, an interim analysis in 500 patients with metastatic BCC or locally advanced BCC showed a response rate of $64.9 \%$ [44]. 


\section{Conclusion}

In summary, the standard of care for local treatment of high-risk BCC includes several options such as surgical excision, MMS or radiotherapy. When BCC progresses to an advanced state, in some cases lesions are no longer suitable for surgery, while in other cases surgery would result in substantial morbidity or deformity and systemic treatment is scarce. The inhibition of the Hedgehog pathway is a new strategy that challenges the actual and future options of treatment for metastatic BCC and locally advanced BCC patients.

Acknowledgments The authors would like to acknowledge Dr Isaac Zilinsky, Mohs Surgery Unit, Sheba Medical Center, Tel Aviv, Israel, and Dr Bennassar, Dermatology Department, Hospital Clinic, Barcelona, Spain, for the images of a case of Mohs surgery. The authors would like also to acknowledge the editorial assistance of TFS Develop Spain in the preparation of this manuscript.

Conflict of interest The authors have received honoraria as part of an advisory board or as speakers for Roche Pharma. The authors have participated in clinical trials exponsored by Roche Pharma.

Open Access This article is distributed under the terms of the Creative Commons Attribution License which permits any use, distribution, and reproduction in any medium, provided the original author(s) and the source are credited.

\section{References}

1. Gailani MR, Leffell DJ, Ziegler A, Gross EG, Brash DE, Bale AE. Relationship between sunlight exposure and a key genetic alteration in basal cell carcinoma. J Natl Cancer Inst. 1996;88:349-54.

2. Diffey BL, Langtry JAA. Skin cancer incidence and the ageing population. Br J Dermatol. 2005;153:679-80.

3. National Comprehensive Cancer Network. NCCN Guideline for Treatment of Basal Cell Skin Cancer. http://www.nccn.org/professionals/physician_gls/pdf/ nmsc/pdf (2013). Available from: http://www.nccn.org/professionals/ physician_gls/pdf/nmsc/pdf

4. Rubin AI, Chen EH, Ratner D. Basal-cell carcinoma. N Engl J Med. 2005;353:2262-9.

5. Kyrgidis A, Vahtsevanos K, Tzellos TG, Xirou P, Kitikidou K, Antoniades K, et al. Clinical, histological and demographic predictors for recurrence and second primary tumours of head and neck basal cell carcinoma. A 1062 patientcohort study from a tertiary cancer referral hospital. Eur J Dermatol. 2010;20:276-82.

6. Telfer NR, Colver GB, Morton CA. British Association of Dermatologists. Guidelines for the management of basal cell carcinoma. $\mathrm{Br} \mathrm{J}$ Dermatol. 2008:159:35-48

7. Von Hoff DD, LoRusso PM, Rudin CM, Reddy JC, Yauch RL, Tibes R, et al Inhibition of the hedgehog pathway in advanced basal-cell carcinoma. N Engl J Med. 2009;361:1164-72.

8. Sekulic A, Migden MR, Oro AE, Dirix L, Lewis KD, Hainsworth JD, et al. Efficacy and safety of vismodegib in advanced basal-cell carcinoma. N Engl J Med. 2012;366:2171-9.

9. Von Domarus H, Stevens PJ. Metastatic basal cell carcinoma. Report of five cases and review of 170 cases in the literature. J Am Acad Dermatol. 1984;10:1043-60.

10. Wadhera A, Fazio M, Bricca G, Stanton O. Metastatic basal cell carcinoma: a case report and literature review. How accurate is our incidence data? Dermatol Online J. 2006;12:7.

11. Dandurand M, Petit T, Martel P, Guillot B. ANAES. Management of basal cell carcinoma in adults clinical practice guidelines. Eur $\mathrm{J}$ Dermatol. 2006;16:394-401.

12. Crowson AN. Basal cell carcinoma: biology, morphology and clinical implications. Mod Pathol Off J US Can Acad Pathol Inc. 2006;19(Suppl 2):S127-47.
13. Lear JT, Smith AG. Basal cell carcinoma. Postgrad Med J. 1997;73:538-42.

14. Berlin JM, Warner MR, Bailin PL. Metastatic basal cell carcinoma presenting as unilateral axillary lymphadenopathy: report of a case and review of the literature. Dermatol Surg Off Publ Am Soc Dermatol Surg Al. 2002;28:1082-4.

15. Sterry W. European dermatology forum guideline committee. Guidelines: the management of basal cell carcinoma. Eur J Dermatol. 2006;16:467-75.

16. Snow SN, Sahl W, Lo JS, Mohs FE, Warner T, Dekkinga JA, et al. Metastatic basal cell carcinoma. Report of five cases Cancer. 1994;73:328-35.

17. Boulinguez S, Grison-Tabone C, Lamant L, Valmary S, Viraben R, Bonnetblanc $\mathrm{JM}$, et al. Histological evolution of recurrent basal cell carcinoma and therapeutic implications for incompletely excised lesions. $\mathrm{Br} \mathrm{J}$ Dermatol. 2004;151:623-6.

18. Weinstein MC, Brodell RT, Bordeaux J, Honda K. The art and science of surgical margins for the dermatopathologist. Am J Dermatopathol. 2012;34:737-45.

19. Ad Hoc Task Force, Connolly SM, Baker DR, Coldiron BM, Fazio MJ, Storrs PA, et al. AAD/ACMS/ASDSA/ASMS 2012 appropriate use criteria for Mohs micrographic surgery: a report of the American Academy of Dermatology, American College of Mohs Surgery, American Society for Dermatologic Surgery Association, and the American Society for Mohs Surgery. J. Am. Acad. Dermatol. 2012;67:531-50.

20. Asgari MM, Olson JM, Alam M. Needs assessment for Mohs micrographic surgery. Dermatol Clin. 2012;30:167-75.

21. Toll A. The implantation of mohs micrographic surgery in Spain: a work still in progress. Actas Dermo Sifiliográficas. 2012;103:759-61.

22. Smeets N. Little evidence available on treatments for basal cell carcinoma of the skin. Cancer Treat Rev. 2005;31:143-6.

23. Mosterd K, Krekels GAM, Nieman FH, Ostertag JU, Essers BAB, Dirksen CD, et al. Surgical excision versus Mohs' micrographic surgery for primary and recurrent basal-cell carcinoma of the face: a prospective randomised controlled trial with 5-years' follow-up. Lancet Oncol. 2008;9:1149-56.

24. Schwipper V. Invasive basal cell carcinoma of the head and neck (basalioma terebrans). Facial Plast Surg FPS. 2011;27:258-65.

25. Gaudet JE, Walvekar RR, Arriaga MA, Dileo MD, Nuss DW, Pou AM, et al. Applicability of the pittsburgh staging system for advanced cutaneous malignancy of the temporal bone. Skull Base Off J N Am Skull Base Soc Al. 2010;20:409-14.

26. Asilian A, Tamizifar B. Aggressive and neglected basal cell carcinoma. Dermatol Surg Off Publ Am Soc Dermatol Surg Al. 2005;31:1468-71.

27. Varga E, Korom I, Raskó Z, Kis E, Varga J, Oláh J, et al. Neglected Basal cell carcinomas in the 21st century. J Skin Cancer. 2011;2011:392151.

28. Howard GR, Nerad JA, Carter KD, Whitaker DC. Clinical characteristics associated with orbital invasion of cutaneous basal cell and squamous cell tumors of the eyelid. Am J Ophthalmol. 1992;113:123-33.

29. Backous DD, DeMonte F, El-Naggar A, Wolf P, Weber RS. Craniofacial resection for nonmelanoma skin cancer of the head and neck. The Laryngoscope. 2005;115:931-7.

30. Lee WR, Mendenhall WM, Parsons JT, Million RR. Radical radiotherapy for T4 carcinoma of the skin of the head and neck: a multivariate analysis. Head Neck. 1993;15:320-4.

31. Al-Othman MO, Mendenhall WM, Amdur RJ. Radiotherapy alone for clinical T4 skin carcinoma of the head and neck with surgery reserved for salvage. Am J Otolaryngol. 2001;22:387-90.

32. Jaal J, Putnik K. Induction cisplatin-based chemotherapy and following radiotherapy in locally advanced basal cell carcinoma of the skin. Acta Oncol Stockh Swed. 2012;51:952-4.

33. Ozgediz D, Smith EB, Zheng J, Otero J, Tabatabai ZL, Corvera CU. Basal cell carcinoma does metastasize. Dermatol Online J. 2008;14:5.

34. Guthrie TH Jr, McElveen LJ, Porubsky ES, Harmon JD. Cisplatin and doxorubicin. An effective chemotherapy combination in the treatment of advanced basal cell and squamous carcinoma of the skin. Cancer. 1985;55:1629-32.

35. Jefford M, Kiffer JD, Somers G, Daniel FJ, Davis ID. Metastatic basal cell carcinoma: rapid symptomatic response to cisplatin and paclitaxel. ANZ J Surg. 2004;74:704-5.

36. Carneiro BA, Watkin WG, Mehta UK, Brockstein BE. Metastatic basal cell carcinoma: complete response to chemotherapy and associated pure red cell aplasia. Cancer Invest. 2006;24:396-400.

37. Kumar B, Roden D, Vinciullo C, Elliott T. A review of 24 cases of Mohs surgery and ophthalmic plastic reconstruction. Aust NZ J Ophthalmol. 1997;25:289-93.

38. Irvine C, Walker NP, Ramnarain ND, Downes RN, Collin JR. Micrographically controlled excision (Mohs' surgery) of basal cell carcinoma around the eye Combined dermatological surgical clearance and oculoplastic surgical repair. Aust NZ J Ophthalmol. 1992;20:5-10.

39. Inkster C, Ashworth J, Murdoch JR, Montgomery P, Telfer NR, Leatherbarrow B. Oculoplastic reconstruction following Mohs surgery. Eye Lond Engl. 1998;12(Pt 2):214-8.

40. Kakudo N, Ogawa Y, Suzuki K, Kushida S, Kusumoto K. Clinical outcome of surgical treatment for periorbital basal cell carcinoma. Ann Plast Surg. 2009;63:531-5.

41. Nemet AY, Deckel Y, Martin PA, Kourt G, Chilov M, Sharma V, et al. Management of periocular basal and squamous cell carcinoma: a series of 485 cases. Am J Ophthalmol. 2006;142:293-7. 
42. Nassab RS, Thomas SS, Murray D. Orbital exenteration for advanced periorbital skin cancers: 20 years experience. J Plast Reconstr Aesthetic Surg JPRAS. 2007;60:1103-9.

43. Epstein EH. Basal cell carcinomas: attack of the hedgehog. Nat Rev Cancer. 2008;8:743-54

44. Dreno B, Kunstfeld R, Grob JJ, Mortier L, Ascierto P, Licitra L. Vismodegib, a Hedgehog pathway inhibitor, in advanced basal cell carcinoma: an interim analysis of theSTEVIE study in 500 patients. 11th International Congress of the Society for Melanoma Research. 2014.

45. Sekulic A, Migden M, Basset-Seguin N, Garbe C, Gesierich A, Lao C, et al Long-term safety and efficacy of vismodegib in patients with advanced basal cell carcinoma: final update (30-Month) of the pivotal ERIVANCE BCC study. 2014 ASCO Annual Meeting.

46. Bozikov K, Taggart I. Metastatic basal cell carcinoma: is infiltrative/morpheaform subtype a risk factor? Eur J Dermatol. 2006;16:691-2.
47. Fantini F, Gualdi G, Cimitan A, Giannetti A. Metastatic basal cell carcinoma with squamous differentiation: report of a case with response of cutaneous metastases to electrochemotherapy. Arch Dermatol. 2008;144:1186-8.

48. Montgomery L, Macpherson M, Gerig L, Carty K, Fox G, Esche B, et al Simultaneous treatment of multiple basal cell carcinoma lesions. Br J Radiol. 2008;81:e290-2.

49. Majima Y, Hirakawa S, Kito Y, Suzuki H, Koide M, Fukamizu H, et al. Twist1 as a possible biomarker for metastatic basal cell carcinoma. Acta Derm Venereol. 2012;92:621-2.

50. Mencía-Gutiérrez E, Gutiérrez-Díaz E, Pérez-Martín ME. Lacrimal caruncle primary basal cell carcinoma: case report and review. J Cutan Pathol. 2005;32:502-5. 